\title{
PENCANTUMAN SERTIFIKAT KEANDALAN (LOGO TRUSTMARK) SEBAGAI BENTUK PERLINDUNGAN KONSUMEN E-COMMERCE DITINJAU DARI PERATURAN YANG BERLAKU
}

\author{
Nathania Tesalonica, Bernadetta Tjandra Wulandari \\ Fakultas Hukum Universitas Katolik Indonesia Atma Jaya \\ bernadetta.wd@gmail.com
}

Submitted: 2021-08-10 | Reviewed: 2021-08-30 | Accepted: 2021-11-08

\begin{abstract}
How to cite: Nathania Tesalonica, Bernadetta Tjandra Wulandari. "Pencantuman Sertifikat Keandalan (Logo Trustmark) Sebagai Bentuk Perlindungan Konsumen E-Commerce Ditinjau dari Peraturan yang Berlaku". Dialogia Iuridica: Jurnal Hukum Bisnis dan Investasi, Vol. 13, No. 1, (2021), 079-096.
\end{abstract}

DOI:

https://doi.org/10.28932/di.v13i1.3874

\begin{abstract}
The development of information and communication technology that is increasing has made a major contribution to meeting human needs. The presence of the internet provides convenience in making buying and selling transactions, through e-commerce. The presence of Law no. 19 of 2016 concerning Amendments to Law Number 11 of 2008 concerning Information and Electronic Transactions is one of the legal instruments in protecting e-commerce consumers. The law regulates one form of protection that can be carried out through the inclusion of a certificate of reliability (trustmark). Based on the analysis using the normative juridical research method, it was found that in the case of the inclusion of a reliability certificate (trustmark) issued by a Foreign Reliability Certification Agency, the government has not taken legal action regarding this matter, so that the inclusion of a reliability certificate (trustmark) can still be applied as long as there are no regulations issued. Arrange. In relation to legal actions that can be taken by the parties for losses in e-commerce transactions due to the absence of a trustmark logo, namely by imposing sanctions on business actors and
\end{abstract}


consumers can demand rights that should be fulfilled in buying and selling transactions through existing mechanisms.

Keywords: Trustmark, Consumer, Protection, ECommerce

\section{PENDAHULUAN}

Perkembangan dalam teknologi informasi dan komunikasi saat ini semakin meningkat dengan cepat. Sejak dikenalnya internet pada kisaran tahun 1900-an, internet telah menjadi kebutuhan mendasar bagi seluruh kalangan masyarakat di dunia. Kehadiran internet memberikan kontribusi besar untuk membantu manusia menjalankan berbagai aktifitas dengan cara yang lebih praktis dibanding sebelumnya. Dengan adanya media internet, jarak dan waktu tidak lagi menjadi hambatan setiap orang untuk melakukan transaksi. Selain untuk berkomunikasi, internet kini telah berkembang juga menjadi media dalam transaksi jual beli. Meningkatnya perkembangan teknologi dari hari ke hari ini tentunya memiliki dampak terhadap banyak bidang, salah satunya perdagangan. Transaksi perdagangan saat ini telah berkembang pesat, tidak lagi hanya dilaksanakan secara konvensional dimana pelaku usaha dan konsumen bertemu secara langsung, tetapi juga dilaksanakan secara elektronik/digital. Hal ini tidak terlepas dari perkembangan teknologi informasi selain juga kebutuhan masyarakat yang ingin bertransaksi lebih cepat, efisien, dan praktis ${ }^{1}$. Melalui kemajuan teknologi, dunia bisnis dapat melaksanakan transaksinya dimana saja dan kapan saja sejauh terdapat jaringan internet. Dengan $e$ commerce, seorang penjual tidak harus bertemu langsung dengan pembeli dalam suatu transaksi bisnis. Transaksi bisa terjadi melalui e-mail, telekopi dan bentuk lainnya, selain itu pembayaran pun juga dapat dilakukan melalui internet ${ }^{2}$.

Di Indonesia, ketentuan mengenai e-commerce atau transaksi perdagangan melalui sistem elektronik secara khusus diatur dalam beberapa peraturan, antara lain dalam Undang-Undang No. 7 Tahun 2014 tentang Perdagangan dan Undang-Undang No. 19 Tahun 2016 Perubahan Atas Undang-Undang No. 11 Tahun 2008 Tentang Informasi dan Transaksi Elektronik berikut peraturan pelaksananya. Aspek keamanan dan keselamatan dalam transaksi perdagangan melalui sistem elektronik, dapat dijumpai dalam peraturan tersebut di atas, antara lain mengenai kewajiban pencantuman sertifikat keandalan (logo trustmark). Dimana dalam hal ini sertifikat keandalan (logo trustmark) dikeluarkan oleh Lembaga Sertifikasi Keandalan yang berdomisili di Indonesia dan terdaftar dalam daftar

\footnotetext{
${ }^{1}$ Bernadetta Tjandra Wulandari, Transaksi Elektronik dalam Perspektif Hak dan Kewajiban Hukum dalam buku Bunga Rampai: Berbagai Aspek Hukum dalam Transaksi secara Digital di Masa Pandemi COVID-19, Jakarta: Universitas Katolik Indonesia Atma Jaya, 2021, hlm.5.

${ }^{2}$ Riyeke Ustadiyanto, Framework E-Commerce, Yogyakarta: Andi, 2001, hlm 138.
} 
Dialogia Iuridica: Jurnal Hukum Bisnis dan Investasi

Volume 13 Nomor 1, November 2021

Lembaga Sertifikasi Keandalan yang diterbitkan oleh Menteri Komunikasi dan Informatika Republik Indonesia.

Pencantuman logo sertifikat keandalan (logo trustmark) menjadi satu hal penting dalam sistem perdagangan secara elektronik, dikarenakan selain sebagai salah satu bentuk perlindungan hukum bagi konsumen e-commerce, juga tercantum dalam Pasal 10 ayat (1) Undang-Undang No. 19 Tahun 2016 Perubahan Atas Undang-Undang No. 11 Tahun 2008 Tentang Informasi dan Transaksi Elektronik yang menyatakan: setiap pelaku usaha yang menyelenggarakan Transaksi Elektronik dapat disertifikasi oleh Lembaga Sertifikasi Keandalan. Selain dalam pasal di atas, ketentuan mengenai hal ini dijumpai juga dalam Pasal 21 ayat (1) huruf e Peraturan Pemerintah No. 80 Tahun 2019 tentang Perdagangan Melalui Sistem Elektronik yang menyatakan:

"PMSE dalam negeri dan/atau PMSE luar negeri wajib:

e. memenuhi ketentuan persyaratan teknis yang ditetapkan oleh instansi terkait dan memperoleh Sertifikat Keandalan sesuai dengan ketentuan peraturan perundang-undangan.

Dalam pasal tersebut dinyatakan bahwa pencantuman sertifikat keandalan (logo trustmark) merupakan suatu kewajiban. Namun demikian walaupun hingga saat ini di Indonesia lembaga tersebut belum terbentuk, namun dalam praktek ditemukan beberapa pelaku usaha e-commerce mencantumkan logo trustmark yang diperoleh dari lembaga sertifikasi asing.

Oleh karenanya terkait dengan uraian tersebut di atas, maka beberapa permasalahan yang akan dibahas dalam tulisan ini antara lain terkait dengan legalitas pencantuman sertifikat keandalan (logo trustmark) yang diterbitkan Lembaga Sertifikasi Keandalan Asing oleh pelaku usaha yang menyelenggarakan transaksi elektronik di Indonesia dan juga mengenai tindakan hukum para pihak atas kerugian dalam transaksi e-commerce akibat tidak tercantumnya sertifikat keandalan (logo trustmark) oleh pelaku usaha. Dalam pembahasannya menggunakan metode yuridis normatif dengan mendasarkan pada data sekunder yang juga menyertakan data dari para nasumber sebagai data pendukung dalam uraian analisanya, yakni dari Kementerian Komunikasi dan Informatika Republik Indonesia dan dari Kementerian Perdagangan Republik Indonesia.

\section{PEMBAHASAN}

\section{Legalitas Pencantuman Sertifikat Keandalan Yang Diterbitkan Oleh Lembaga Sertifikasi Keandalan Asing}

Berdasar Cambridge Dictionary, sertifikasi adalah:

a. "The process of earning an official document, or the act of providing an official document, as proof that something has happened or been done". 
Dialogia luridica: Jurnal Hukum Bisnis dan Investasi

Volume 13 Nomor 1, November 2021

b. "The process of giving official or legal approval to a person, company, product, etc. that has reached a particular standard",

Sertifikasi juga dapat didefinisikan suatu prosedur pihak ketiga memberikan jaminan tertulis bahwa suatu produk, proses atau jasa sesuai dengan karakteristik yang spesifik $^{4}$. Menurut Emma Nurita, sertifikasi adalah suatu prosedur dimana pihak ketiga memberikan jaminan tertulis bahwa suatu produk, proses atas jasa telah memenuhi standar ketentuan tertentu, berdasarkan audit yang dilaksanakan dengan prosedur yang disepakati ${ }^{5}$. Sertifikat keandalan merupakan salah satu bentuk sertifikasi yang ditunjukan dengan adanya logo trust pada websitenya. Di beberapa negara, sertifikat keandalan lebih dikenal dengan istilah trustmark.

Pada Pasal 1 angka 27 Peraturan Pemerintah No. 71 Tahun 2019 tentang Penyelenggaraan Sistem dan Transaksi Elektronik dinyatakan Sertifikat Keandalan adalah dokumen yang menyatakan pelaku usaha yang menyelenggarakan transaksi elektronik telah lulus audit atau uji kesesuaian dari Lembaga Sertifikasi Keandalan. Dalam Pasal 74 ayat (2) Peraturan Pemerintah No. 71 Tahun 2019 tentang Penyelenggaraan Sistem dan Transaksi Elektronik, dijelaskan pula bahwa sertifikat keandalan adalah suatu jaminan bahwa pelaku usaha telah memenuhi kriteria yang telah ditentukan oleh Lembaga Sertifikasi Keandalan. Pencantuman sertifikat keandalan (logo trustmark) bertujuan untuk melindungi konsumen dalam transaksi elekronik. Sertifikasi Keandalan dimaksudkan sebagai bukti bahwa pelaku usaha yang melakukan perdagangan secara elekronik layak berusaha setelah melalui penilaian dan audit dari badan yang berwenang. Sebagaimana diatur dalam Pasal 10 ayat (1) Undang-Undang No.11 Tahun 2008 tentang Informasi dan Transaksi Elektronik: setiap pelaku usaha yang menyelenggarakan Transaksi Elektronik dapat disertifikasi oleh Lembaga Sertifikasi Keandalan. Dalam penjelasan pasalnya dinyatakan:

Sertifikasi Keandalan dimaksudkan sebagai bukti bahwa pelaku usaha yang melakukan perdagangan secara elektronik layak berusaha setelah melalui penilaian dan audit dari badan yang berwenang. Bukti telah dilakukan Sertifikasi Keandalan ditunjukkan dengan adanya logo sertifikasi berupa trust mark pada laman (home page) pelaku usaha tersebut.

Proses sertifikasi keandalan ini mencakup pemeriksaan terhadap informasi yang lengkap dan benar dari pelaku usaha beserta sistem elektroniknya, termasuk namun tidak terbatas pada informasi yang memuat identitas pelaku usaha, kebijakan dan prosedur perlindungan privasi, kebijakan dan prosedur pengamanan sistem, dan pernyataan

\footnotetext{
${ }^{3}$ Cambridge Dictionary, "Certification", https://dictionary.cambridge.org/dictionary/english/certification, ditelusuri pada 1 Maret 2021.

${ }^{4}$ Paolo Balboni, Trustmarks- Third Party Liability of Trustmark Organisations in Europe, Thesis, 2008, hlm.10.

${ }^{5}$ Zainatun Rossalina, et.al, "Keabsahan Akta Notaris yang Menggunakan Cyber Notary sebagai Akta Otentik", Jurnal Hukum Universitas Brawijaya, 2016, hlm. 16.
} 
Dialogia Iuridica: Jurnal Hukum Bisnis dan Investasi

Volume 13 Nomor 1, November 2021

jaminan atas barang dan/atau jasa yang ditawarkan, sebagaimana dicantumkan dalam Pasal 75 ayat (3) Peraturan Pemerintah No. 71 Tahun 2019 tentang Penyelenggaraan Sistem dan Transaksi Elektronik,:

(3) Informasi yang lengkap dan benar sebagaimana dimaksud pada ayat (2) termasuk namun tidak terbatas pada informasi yang: a. memuat identitas Pelaku Usaha; b. memuat kebijakan dan prosedur pelindungan pnvast; c. memuat kebijakan dan prosedur pengamanan sistem; dan d. memuat pernyataan jaminan atas barang danjatau jasa yang ditawarkan.

Dalam penjelasan Pasal 10 ayat (1) Undang-Undang No. 19 Tahun 2016 tentang Perubahan Atas Undang-Undang No. 11 Tahun 2008 tentang Informasi dan Transaksi Elektronik disebutkan bahwa sertifikat keandalan dimaksudkan sebagai bukti bahwa pelaku usaha yang melakukan perdagangan secara elektronik layak berusaha setelah melalui penilaian dan audit dari badan yang berwenang. Bukti telah dilakukan sertifikasi keandalan ditunjukkan dengan adanya logo sertifikasi berupa trustmark pada laman (home page) pelaku usaha tersebut. Tujuan sertifikat keandalan tertuang di dalam Pasal 74 ayat (1) Peraturan Pemerintah No. 71 Tahun 2019 tentang Penyelenggaraan Sistem dan Transaksi Elektronik, yaitu sertifikat keandalan bertujuan melindungi konsumen dalam transaksi elektronik, sedangkan fungsi sertifikat keandalan (trustmark) merupakan sebagai jaminan bahwa pelaku usaha telah memenuhi kriteria yang ditentukan oleh Lembaga Sertifikasi Keandalan.

Adanya pencantuman sertifikat keandalan (logo trustmark) dalam laman website pelaku usaha menunjukan kepada konsumen bahwa website tersebut telah melalui verifikasi sehingga aspek keamanan untuk melakukan transaksi perdagangan secara elektronik telah terpenuhi, melalui tampilan logo yang diterbitkan oleh lembaga yang berwenang. Pemberian sertifikat keandalan (logo trustmark) di Indonesia diatur berdasarkan Pasal 76 ayat (1) Peraturan Pemerintah No. 71 Tahun 2019 tentang Penyelengaraan Sistem dan Transaksi Elektronik yang meliputi tiga kategori sebagai berikut:

1. Registrasi identitas, yang merupakan sertifikat keandalan yang jaminan keandalannya sebatas pengamanan bahwa identitas pelaku usaha adalah benar. Validasi yang dilakukan oleh Lembaga Sertifikasi Keandalan hanya terhadap identitas pelaku usaha yang paling sedikit memuat nama subjek hukum, status subjek hukum, alamat atau kedudukan, nomor telepon, alamat email, izin usaha, dan Nomor Pokok Wajib Pajak (NPWP) apabila belum terdaftar dalam sistem Perizinan Berusaha Terintegrasi Elektronik/Online Single Submission. Lembaga Sertifikasi Keandalan yang menerbitkan sertifikat keandalan ini memberikan kepastian penelusuran bahwa identitas pelaku usaha adalah benar.

2. Keamanan sistem elektronik, yang merupakan sertifikat keandalan yang jaminan keandalannya memberikan kepastian bahwa proses penyampaian atau pertukaran data melalui website pelaku. Usaha dilindungi keamanannya 
Dialogia luridica: Jurnal Hukum Bisnis dan Investasi

Volume 13 Nomor 1, November 2021

dengan menggunakan teknologi pengamanan proses pertukaran data seperti protokol SSL/secure socket layer. Sertifikat Keandalan ini menjamin bahwa terdapat sistem pengamanan dalam proses pertukaran data yang telah teruji. Pengamanan terhadap kerawanan (vulnerability seal) merupakan sertifikat keandalan yang jaminan keandalannya adalah memberikan kepastian bahwa terdapat sistem manajemen keamanan informasi yang diterapkan oleh pelaku usaha dengan mengacu pada standar pengamanan sistem elektronik tertentu berdasarkan ketentuan peraturan perundang-undangan.

3. Kebijakan privasi, yang merupakan sertifikat keandalan yang jaminan keandalannya adalah memberikan kepastian bahwa data pribadi konsumen dilindungi kerahasiaannya sebagaimana mestinya.

Meskipun hingga saat ini Lembaga Sertifikasi Keandalan belum terbentuk di Indonesia, namun dalam praktiknya terdapat perusahaan yang telah menggunakan sertifikat keandalan (logo trustmark) yang diterbitkan oleh Lembaga Sertifikasi Keandalan Asing salah satunya blibli.com. Blibli merupakan suatu marketplace yang dalam laman (home page) Blibli tercantum logo yang menyatakan keamanan sistem yang telah tersertifikasi oleh lembaga yang mengeluarkan yaitu lambang Norton Secured. Norton berada di bawah Symantec, perusahaan yang memproduksi software pengamanan berbasis di Amerika Serikat. Dengan demikian dapat dikatakan lembaga yang mengeluarkan adalah lembaga sertifikasi asing. Sedangkan jika dilihat baik dalam Undang-Undang No. 19 Tahun 2016 Perubahan Atas Undang-Undang No. 11 Tahun 2008 Tentang Informasi dan Transaksi Elektronik maupun Peraturan Pemerintah No. 80 Tahun 2019 Tentang Perdagangan dengan Sistem Elektronik tidak mengatur secara spesifik terkait pencantuman sertifikat keandalan (logo trustmark) yang diperoleh dari lembaga sertifikasi asing.

Lebih lanjut dalam Pasal 73 ayat (2) dan (5) Peraturan Pemerintah No. 71 Tahun 2019 tentang Penyelenggaraan Sistem dan Transaksi Elektronik dinyatakan bahwa Lembaga Sertifikasi Keandalan harus berdomisili di Indonesia dan terdaftar dalam daftar Lembaga Sertifikasi Keandalan yang diterbitkan oleh Menteri Komunikasi dan Informatika Republik Indonesia. Jika dikaitkan dengan pencantuman logo trustmark yang diperoleh dari lembaga sertifikasi asing, tidak serta merta dikatakan sebagai sesuatu yang illegal, karena dalam Peraturan Pemerintah No. 71 Tahun 2019 tentang Penyelenggara Sistem dan Transaksi Elektronik tidak menjelaskan ketentuan lebih lanjut terkait hal tersebut, sehingga, pihak berwenang tidak akan memberikan larangan atau tindakan hukum terkait hal tersebut.

Dengan demikian saat ini pencantuman sertifikat keandalan yang diterbitkan dari lembaga sertifikasi asing tersebut masih dapat diterapkan sampai ada pengaturan lebih lanjut. Berdasarkan pada informasi yang diperoleh dari narasumber, kedepannya akan dibuat kebijakan bahwa untuk Penyelenggara Sistem Elektronik Indonesia, pencantuman sertifikat keandalan (logo trustmark) harus dikeluarkan oleh Lembaga Sertifikasi 
Dialogia Iuridica: Jurnal Hukum Bisnis dan Investasi

Volume 13 Nomor 1, November 2021

Keandalan Indonesia, sedangkan untuk Penyelenggara Sistem Elektronik Asing boleh menggunakan Lembaga Sertifikasi Keandalan Asing sepanjang memenuhi kriteria yang dipersyaratkan. Terkait dengan perusahaan yang telah mencantumkan sertifikat keandalan (logo trustmark) dari Lembaga Sertifikasi Asing tersebut, apabila memang dipandang perlu, maka setiap Penyelenggara Sistem Elektronik Indonesia harus menyesuaikan dengan aturan tersebut (apabila memang harus disertifikasi ulang) dalam jangka waktu tertentu.

Pada dasarnya, jika pencantuman sertifikat keandalan (logo trustmark) sudah diatur secara lebih jelas dan tegas, hal tersebut dapat memberikan kepastian hukum terkait legalitas sertifikat keandalan (logo trustmark) yang diterbitkan oleh Lembaga Sertifikasi Keandalan Asing, terlebih lagi dalam Pasal 21 ayat (1) huruf e Peraturan Pemerintah No. 80 Tahun 2019 Tentang Perdagangan dengan Sistem Elektronik memberikan kewajiban pencantuman sertifikat keandalan (logo trustmark) terhadap Penyelenggara Perdagangan Melalui Sistem Elektronik (PPMSE). Kejelasan dan ketegasan terkait ketentuan pencantuman sertifikat keandalan dari lembaga asing, tentunya akan memberikan kemudahan, khususnya bagi konsumen untuk mengetahui mana sertifikat keandalan (logo trustmark) yang dikeluarkan oleh Lembaga Sertifikasi Keadalan yang terjamin keamanannya dan terdaftar dalam daftar Lembaga Sertifikasi Keandalan yang diterbitkan Menteri Komunikasi dan Informatika Republik Indonesia sehingga, ketika ada permasalahan antara konsumen dengan penyelenggara sistem elektronik ataupun pelaku usaha yang menggunakan jasa Lembaga Sertifikasi Keandalan yang terdaftar, Kementerian Komunikasi dan Informatika Republik Indonesia dapat melakukan tindakan teguran atau tindak lanjut lainnya. ${ }^{6}$

\section{Tindakan Hukum Para Pihak atas Kerugian dalam Transaksi E-Commerce Akibat Tidak Tercantumnya Sertifikat Keandalan (Logo Trustmark)}

E-commerce menurut Kalakota dan Winston dapat dilihat dari beberapa perspektif, yaitu:

1. Dari perspektif komunikasi, e-commerce adalah pengiriman barang, layanan, informasi, atau pembayaran melalui jaringan komputer atau melalui peralatan elektronik lainnya.

2. Dari perspektif proses bisnis, e-commerce adalah aplikasi dari teknologi yang menuju otomatisasi dari transaksi bisnis dan aliran kerja.

3. Dari perspektif layanan, e-commerce merupakan suatu alat yang memenuhi keinginan perusahaan, konsumen, dan manajemen untuk memangkas biaya layanan (service cost) ketika meningkatkan kualitas barang dan meningkatkan kecepatan layanan pengiriman.

\footnotetext{
${ }^{6}$ Eka Nugraha Putra, et.al, "Efektivitas Pelaksanaan Sertifikasi Keandalan Website Jual Beli Online dalam Menanggulangi Penipuan Konsumen”, Jurnal Cakrawala Hukum, Vol.8 No.2, 2017, hlm.156.
} 
Dialogia luridica: Jurnal Hukum Bisnis dan Investasi

Volume 13 Nomor 1, November 2021

4. Dari perspektif online, e-commerce menyediakan kemampuan untuk membeli dan menjual barang ataupun informasi melalui internet dan sarana online lainnya ${ }^{7}$.

Pada dasarnya transaksi e-commerce memiliki karaktertisitik yang berbeda dengan transaksi perdagangan biasa (konvensional), diantaranya seperti:

a. Transaksi tanpa batas

Sebelumnya, letak geografis menjadi salah satu kendala suatu perusahaan besar yang ingin menjangkau pasar di luar negeri. Namun, e-commerce memanfaatkan kemajuan teknologi yang memungkinkan terjadinya transaksi lintas negara. Transaksi dalam e-commerce dapat dilakukan oleh semua pihak tanpa adanya batasan wilayah dan dapat dinikmati juga oleh semua pengusaha.

b. Transaksi anonim

Dalam transaksi e-commerce, penjual dan pembeli tidak harus lagi bertemu secara langsung, tetapi dapat menggunakan teknologi internet sebagai media transaksi. Selain itu, penjual tidak memerlukan nama dari pembeli sepanjang mengenai pembayarannya telah diotorisasi oleh penyedia sistem pembayaran yang ditentukan, yang biasanya dengan kartu kredit.

c. Produk digital dan non digital

Produk-produk yang ditawarkan dalam e-commerce dapat berupa digital dan non-digital. Produk-produk digital seperti software komputer, musik dan produk lain yang bersifat digital dan dapat dipasarkan melalui internet dengan cara men-download secara elektronik. Sedangkan, produk non-digital meliputi barang-barang kebutuhan hidup lainnya seperti: pakaian, perabotan rumah tangga, dan lainnya.

d. Produk barang tak berwujud.

Banyak perusahaan yang bergerak di bidang e-commerce dengan menawarkan barang tak berwujud seperti data, software dan ide-ide yang dijual melalui internet. $^{8}$

Undang-Undang No. 7 Tahun 2014 tentang Perdagangan sebagaimana tercantum dalam Pasal 1 angka 24 memberikan batasan perdagangan melalui sistem elektronik adalah perdagangan yang transaksinya dilakukan melalui serangkaian perangkat dan prosedur elektronik. Sedangkan Pasal 1 angka 2 Undang-Undang No. 19 Tahun 2016 tentang Perubahan Atas Undang-Undang No. 11 Tahun 2008 tentang Informasi dan Transaksi Elektronik menjelaskan juga bahwa transaksi elektronik adalah perbuatan hukum yang dilakukan dengan menggunakan komputer, jaringan komputer, dan/atau media elektronik lainnya.

\footnotetext{
${ }^{7}$ Arsyad Sanusi, Hukum E-Commerce, Jakarta: Sasrawarna Printing, 2011, hlm. 217-218.

${ }^{8}$ Nufransa Wira Sakti, "Perpajakan dalam E-Commerce, Belajar dari Jepang”, Berita Pajak No. 1443/Tahun XXXIII, 2001, hlm. 35.
} 
Dialogia Iuridica: Jurnal Hukum Bisnis dan Investasi

Volume 13 Nomor 1, November 2021

Transaksi e-commerce memiliki karakteristik yang berbeda dengan transaksi konvensional, hal ini bukan saja berkaitan dengan jenis barang yang diperjualbelikan juga bukan hanya terbatas pada penawaran dan permintaan saja, melainkan terkait dengan jangkauan dan lingkup pemasaran yang lebih luas. Dalam transaksi e-commerce pembeli dan penjual terkadang tidak berada dalam suatu wilayah atau negara yang sama. Hal ini tentunya dapat menimbulkan permasalahan antara lain dalam proses pengiriman barang, seperti barang yang dipesan tidak sampai, ataupun sampai dengan keadaan cacat/rusak, mekanisme complain yang sulit dan juga pemanfaatan data pribadi secara melawan hukum. Selain itu perselisihan dalam hal ini juga akan memunculkan persoalan baru terkait yuridiksi ${ }^{9}$.

Konsumen sebelum mulai melakukan transaksi melalui e-commerce, diharuskan untuk memberi informasi yang lengkap dan benar mengenai identitas diri. Namun, tidak ada jaminan bahwa data diri/identitas konsumen tidak akan disalahgunakan oleh pelaku usaha seperti untuk pengiriman brosur pemasaran perusahaan atau bahkan digunakan untuk tindak penipuan. Hal ini menjadi salah satu kelemahan dan potensi kerugian dalam transaksi e-commerce terkait data pribadi dan privasi konsumen, terutamanya berkaitan dengan metode pembayaran, pemasaran, dan penawaran ${ }^{10}$.

Terkait dengan tindakan hukum terhadap pelaku usaha, dalam Pasal 7 huruf $b$ Undang-Undang No. 8 Tahun 1999 tentang Perlindungan Konsumen dinyatakan pelaku usaha diwajibkan untuk memberikan informasi yang benar, jelas dan jujur mengenai kondisi dan jaminan barang dan/atau jasa serta memberi penjelasaan penggunaan, perbaikan, dan pemeliharaan. Hal ini disebabkan karena informasi tersebut merupakan hak konsumen, apabila tidak adanya informasi yang tidak memadai dari pelaku usaha dapat menimbulkan cacat produk (berupa cacat informasi), yang akan sangat merugikan konsumen. Pelaku usaha juga harus beritikad baik dalam melakukan kegiatan usahanya dan menjamin kualitas barang dan/atau jasa yang diperdagangkan karena pada dasarnya diaturnya kewajiban pelaku usaha ini bertujuan untuk melindungi konsumen agar terhindar dari kerugian. Salah satu cara menumbuhkan kepercayaam tersebut melalui pencantuman sertifikat keandalan (logo trustmark) ini. Melihat potensi kerugian yang akan muncul dalam perdagangan secara elektronik juga menunjukan pentingnya pencantuman sertifikat keandalan (logo trustmark).

Adanya pencantuman sertifikat keandalan (logo trustmark) merupakan salah satu bentuk perlindungan konsumen dalam transaksi e-commerce, hal ini dikarenakan adanya risiko ketika melakukan transaksi melalui e-commerce. Tindakan penipuan dan penyalahgunaan data konsumen merupakan salah satu bentuk kerugian yang dapat dialami ketika melakukan transaksi melalui e-commerce. Dengan tidak adanya sertifikat keandalan (logo trustmark) pada laman (home page) maka, akan makin terbuka

\footnotetext{
${ }_{9}^{9}$ Valerie Paskalia Selvie, "Perlindungan Konsumen dalam Transaksi Electronic Commerce: Perspektif Australia", Legality, Vol.11 No.1, 2003, hlm.41.

${ }_{10}$ Op.cit, Bunga Rampai: Berbagai Aspek Hukum dalam Transaksi secara Digital di Masa Pandemi COVID-19, Laksana Arum Nugraheni, dalam Bab Perlindungan Hukum Terhadap Data Pribadi Konsumen dalam Transaksi Elektronik di Masa Pandemi COVID-19, hlm.128.
} 
Dialogia Iuridica: Jurnal Hukum Bisnis dan Investasi

Volume 13 Nomor 1, November 2021

kemungkinan resiko kerugian akibat dari tindakan hacker atau pencurian data. Dalam hal adanya kerugian yang muncul akibat tidak tercantumnya sertifikat keandalan (logo trustmark), terdapat dua tindakan hukum yang dapat dilakukan para pihak yaitu pengenaan sanksi terhadap pelaku usaha dan tuntutan pidana maupun pemenuhan hak berupa gantirugi yang dilakukan oleh konsumen.

Pada Pasal 21 ayat (1) huruf e Peraturan Pemerintah No. 80 Tahun 2019 Tentang Perdagangan dengan Sistem Elektronik mewajibkan setiap penyelenggara perdagangan melalui sistem elektronik, untuk memiliki sertifikat keandalan. model bisnis yang termasuk dalam kategori Penyelenggara Perdagangan Melalui Sistem Elektronik (PPMSE) antara lain:

a. retail online atau Pedagang yang memiliki sarana PMSE sendiri;

b. marketplace atau penyedia platform pelantar sebagai wadah dimana pedagang dapat memasang penawaran Barang dan/atau Jasa;

c. iklan baris online yaitu suatu platform/pelantar yang mempertemukan penjual dan pembeli dimana keseluruhan proses transaksi terjadi tanpa melibatkan PPMSE;

d. platform/pelantar pembanding harga;

e. daily deals. ${ }^{11}$

Sebagaimana diuraikan di atas, pencantuman sertifikat keandalan (logo trustmark) merupakan suatu kewajiban bagi pelaku usaha dalam upaya melindungi konsumen. Oleh karenanya pelanggaran atasnya akan dikenakan sanksi. Dalam hal pelaku usaha yang melanggar ketentuan dalam Pasal 21 Peraturan Pemerintah No. 80 Tahun 2019 akan dikenai sanksi administartif. Berkaitan dengan pelanggaran Pasal 21 tersebut, Kementerian Komunikasi dan Informatika hanya berwenang memberikan sanksi dengan melakukan pemblokiran layanan PPMSE dalam negeri dan/atau PPMSE luar negeri. Berdasarkan hasil wawancara dengan Ibu Aulia Zulfa, selaku Analis Kebijakan Muda Direktorat Tata Kelola Aplikasi Informatika dan Bapak Fajar Maulana, selaku Analis Kebijakan Pertama Direktorat Tata Kelola Aplikasi Informatika untuk saat ini, pengaturan terkait sanksi akan ditinjau kembali terkait dengan mekanisme penjatuhan sanksi dan tentunya harus selaras dan bersinergi dengan peraturan-peraturan yang terkait. Hal ini dikarenakan apabila didasarkan pada ketentuan yang diatur dalam Peraturan Menteri Perdagangan No. 50 Tahun 2020 tentang Ketentuan Perizinan Usaha, Periklanan, Pembinaan, dan Pengawasan Pelaku Usaha dalam Perdagangan melalui Sistem Elektronik mengatur secara lebih lanjut terkait pelanggaran Pasal 21 Peraturan Pemerintah No. 80 Tahun 2019 tentang Perdagangan Melalui Sistem Elektronik, khususnya terkait sertifikat keandalan (logo trustmark) dan menyatakan sanksinya berupa pemblokiran, maka hal pengajuan pemblokiran diajukan ke Kementerian Komunikasi dan

\footnotetext{
${ }^{11}$ Moderator, "Perdagangan Melalui Sistem Elektronik (PPMSE)", https://www.pajakku.com/forumtopic/5ea13ab1d066f279c7d5c4ae/Perdagangan-Melalui-Sistem-Elektronik-(PPMSE), diakses pada 22 Februari 2021 pk.14.10 WIB.
} 
Dialogia Iuridica: Jurnal Hukum Bisnis dan Investasi

Volume 13 Nomor 1, November 2021

Informatika atas permintaan Kementerian Perdagangan, namun apabila dikenakan sanksi yang lain, maka hal tersebut seharusnya merupakan kewenangan Kementerian Perdagangan. ${ }^{12}$.

Walaupun dalam Peraturan Pemerintah No. 80 Tahun 2019 tentang Perdagangan Melalui Sistem Elektronik mewajibkan PPMSE untuk memiliki sertifikat keandalan (trustmark), dalam praktiknya saat ini belum banyak pelaku usaha mencantumkan sertifikat keandalan (logo trustmark) pada lamannya (home page). Potensi kerugian dan tidak terpenuhinya hak konsumen menjadi sangat terbuka lebar. Hal ini dikarenakan pada dasarnya transaksi konsumen terbagi menjadi beberapa tahap, yakni pra transaksi, transaksi dan purna transaksi. Pada tahap pra-transaksi, aspek informasi menjadi hal terpenting, sehingga pencantuman logo trustmark pada home page menjadi salah satu informasi penting yang juga harus diketahui oleh konsumen sebelum melanjutkan pada tahap selanjutnya.

Ketika melakukan transaksi jual beli, maka akan timbul hubungan hukum antara konsumen dengan pelaku usaha, yang dimana hubungan tersebut menimbulkan akibat hukum terhadap pihak-pihak terkait. Berkaitan dengan ini, terkadang ada salah satu pihak yang dirugikan, terutamanya pihak konsumen. Oleh karena itu, pentingnya hukum perlindungan konsumen yang mengatur terkait hak dan kewajiban pada konsumen dan produsen agar tercapainya tujuan dari hukum perlindungan konsumen.

Keinginan yang hendak dicapai dalam perlindungan konsumen adalah menciptakan rasa aman bagi konsumen dalam memenuhi kebutuhan hidup. Segala upaya yang dimaksudkan dalam perlindungan tersebut bukan hanya terhadap tindakan preventif, melainkan juga tindakan represif dalam semua bidang perlindungan yang diberikan terhadap konsumen. Pengaturan perlindungan konsumen tersebut dilakukan dengan:

1. Menciptakan sistem perlindungan konsumen yang mengandung unsur keterbukaan akses dan informasi, serta menjamin kepastian hukum

2. Melindungi kepentingan konsumen pada khususnya dan kepentingan seluruh pelaku usaha

3. Meningkatkan kualitas barang dan pelayanan jasa

4. Memberikan perlindungan kepada konsumen dari praktek usaha yang menipu dan menyesatkan; dan

5. Memadukan penyelenggaraan, pengembangan dan pengaturan perlindungan konsumen dengan bidang-bidang perlindungan pada bidang-bidang lain ${ }^{13}$

Perlindungan hukum terhadap konsumen dapat dilakukan pada saat sebelum terjadinya transaksi (no conflict/pre purchase) dan/atau pada saat setelah terjadinya

\footnotetext{
${ }^{12}$ Berdasarkan hasil wawancara dengan Ibu Aulia Zulfa, Analis Kebijakan Muda dan Bapak Fajar Maulana, Analis Kebijakan Pertama Direktorat Tata Kelola Aplikasi Informatika Kementerian Komunikasi dan Informatika Republik Indonesia, Jakarta 23 April 2021 melalui aplikasi zoom.

${ }^{13}$ Husni Syawali dan Neni Sri Imaniyati, Hukum Perlindungan Konsumen, Bandung: Mandar Maju, 2000, hlm. 7 .
} 
Dialogia Iuridica: Jurnal Hukum Bisnis dan Investasi

Volume 13 Nomor 1, November 2021

transaksi (conflict/post purchase). ${ }^{14}$ Perlindungan hukum terhadap konsumen yang dapat dilakukan pada saat sebelum terjadinya transaksi (no conflict/pre purchase) dapat dilakukan dengan cara antara lain:

1. Legislation, yaitu perlindungan hukum terhadap konsumen yang dilakukan pada saat sebelum terjadinya transaksi dengan memberikan perlindungan kepada konsumen melalui peraturan perundang-undangan yang telah dibuat. Sehingga dengan adanya peraturan perundang tersebut diharapkan konsumen memperoleh perlindungan sebelum terjadinya transaksi, karena telah ada batasan- batasan dan ketentuan yang mengatur transaksi antara konsumen dan pelaku usaha.

2. Voluntary Self Regulation, yaitu perlindungan hukum terhadap konsumen yang dilakukan pada saat sebelum terjadinya transaksi, dimana dengan cara ini pelaku usaha diharapkan secara sukarela membuat peraturan bagi dirinya sendiri agar lebih berhati-hati dan waspada dalam menjalankan usahanya. ${ }^{15}$

Sedangkan untuk perlindungan hukum terhadap konsumen pada saat setelah terjadinya transaksi (conflict/post purchase) dapat dilakukan melalui jalur pengadilan (litigasi) atau di luar pengadilan (non-litigasi) berdasarkan pilihan oleh para pihak yang bersengketa, sebagaimana juga tercantum pada Pasal 45 ayat (2) Undang-Undang No.8 Tahun 1999 tentang Perlindungan Konsumen: penyelesaian sengketa konsumen dapat ditempuh melalui pengadilan atau di luar pengadilan berdasarkan pilihan sukarela para pihak yang bersengketa. Dalam hal penyelesaian sengketa di luar pengadilan dapat dilakukan melalui lembaga yang secara khsusus menangani penyelesian sengketa konsumen yakni Badan Penyelesaian Sengketa Konsumen (BPSK) maupun melalui penyelesaian damai. Dimana dalam penjelasan ayat (2) di atas, dinyatakan bahwa penyelesaian sengketa konsumen sebagaimana dimaksud pada ayat ini tidak menutup kemungkinan penyelesaian damai oleh para pihak yang bersengketa. Pada setiap tahap diusahakan untuk menggunakan penyelesaian damai oleh kedua belah pihak yang bersengketa. Yang dimaksud dengan penyelesaian secara damai adalah penyelesaian yang dilakukan oleh kedua belah pihak yang bersengketa (pelaku usaha dan konsumen) tanpa melalui pengadilan atau badan penyelesaian sengketa konsumen dan tidak bertentangan dengan undang-undang ini. Dari ketentuan Pasal 45 Undang-Undang No.8 Tahun 1999 tentng Perlindungan Konsumen,dijumpai beberapa hal penting bahwa gugatan konsumen melalui lembaga penyelesaian sengketa bukanlah berjenjang melainkan pilihan sukarela para pihak, selain itu penyelesaian melalui lembaga penyelesaian sengketa tidaklah menghapus sifat melawan hukum pidana (UUPK menggunakan istilah "menghilangkan tanggungjawab pidana") dan meskipun para Pihak telah memilih lembaga penyelesaian sengketa di luar pengadilan tersebut, gugatan

\footnotetext{
${ }^{14}$ Johanes Gunawan, Hukum Perlindungan Konsumen, Bandung: Universitas Katolik Parahyangan, 1999, hlm. 3.

${ }^{15} \mathrm{Ibid}, \mathrm{hlm} .4$.
} 
Dialogia Iuridica: Jurnal Hukum Bisnis dan Investasi

Volume 13 Nomor 1, November 2021

melalui pengadilan (peradilan umum) diperkenankan sepanjang upaya yang telah dipilih tersebut gagal (tidak berhasil) ${ }^{16}$.

Perlindungan hukum terhadap konsumen diperlukan karena konsumen seringkali berada dalam posisi yang lemah dalam suatu transaksi konsumen. Adanya perbedaan kepentingan antara pelaku usaha dengan konsumen menyebabkan tidak diperolehnya keuntungan optimal dari penggunaan barang dan/atau jasa tersebut. Dengan adanya perlindungan hukum bagi konsumen, diharapkan dapat memberikan kedudukan hukum yang seimbang antara konsumen dengan pelaku usaha.

Perlindungan hukum tersebut diberikan bukan hanya untuk transaksi jual beli secara konvensional saja, namun juga dalam transaksi e-commerce, yang saat ini mengalami perkembangan yang cukup pesat karena selalu bertambahnya situs belanja online di Indonesia. Ketika seorang konsumen ingin membeli suatu produk secara online, tentu akan adanya resiko yang muncul. Resiko yang dimaksud berupa bentuk kecurangankecurangan, seperti pada virtual store yang bersangkutan merupakan toko fiktif, terjadi keterlambatan pengiriman produk kepada konsumen, adanya kerusakan/cacat atas barang yang dikirimkan, kondisi barang yang diterima tidak sesuai dengan apa yang ditawarkan di internet, dan hal-hal lainnya yang mungkin saja terjadi. ${ }^{17}$ Oleh karena itu diperlukannya adanya jaminan akan kepastian hukum bagi konsumen dalam melakukan transaksi $e$ commerce guna menumbuhkan kepercayaan konsumen dan melindungi dari segala berbagai bentuk kerugian yang muncul.

Dalam hal ini hak-hak konsumen yang berpotensi dilanggar sebagaimana tercantum dalam Undang-Undang No. 8 Tahun 1999 tentang Perlindungan Konsumen dalam Pasal 4 huruf a, terkait hak atas kenyamanan, keamanan dan keselamatan dalam mengonsumsi barang dan/atau jasa dan Pasal 4 huruf $\mathrm{c}$ terkait hak atas informasi yang benar, jelas dan jujur mengenai kondisi dan jaminan barang dan/atau jasa. Sebagai pengguna fasilitas perdagangan secara elektronuik, konsumen tentu berhak atas hak-hak tersebut. Informasi menjadi sesuatu yang penting, karena melalui informasi ini konsumen dapat mengambil keputusan untuk melakukan transaksi atau tidak. Hal ini memperkuat posisi konsumen dalam transaksi elektronik untuk mendapatkan informasi yang benar dan lengkap sekaligus menutup kemungkinan pengalihan beban tanggung jawab kepada konsumen terkait keruginan yang diderita ${ }^{18}$.

Apabila kerugian muncul akibat tidak dicantumkannya sertifikat keandalan (logo trustmark), maka sejogjanya pelaku usaha bertanggung jawab sebagai bentuk kewajiban pelaku usaha untuk senantiasa beritikad baik dalam melakukan kegiatannya. Dalam hal ini terdapat dua perspektif terkait dengan kerugian yang dialami berkenaan dengan keamanan dan kenyamana dalam bertransaksi secara elektronik. Pertama, jika kerugian

\footnotetext{
16 Yusuf Shofie, Sinopsis Dan Komentar Undang-Undang Perlindungan Konsumen (Panduan Bagi Konsumen dan Pelaku Usaha), Jakarta: Perum Percetakan Negara, 2008, hlm.72.

${ }^{17}$ Chyntia Hutagalung, "Perlindungan Hukum Terhadap Konsumen Dalam Kegiatan E-Commerce di Indonesia", https://www.pphbi.com/perlindungan-hukum-terhadap-konsumen-dalam-kegiatan-ecommerce-di-indonesia/, diakses pada tanggal 18 Oktober 2021 pukul 14.25 WIB.

${ }^{18}$ Loc.cit., Bernadetta Tjandra Wulandari, Bunga Rampai, hlm.5.
} 
Dialogia Iuridica: Jurnal Hukum Bisnis dan Investasi

Volume 13 Nomor 1, November 2021

tersebut akibat penyalahgunaan data pribadi, maka hal ini merupakan perbuatan yang memenuhi unsur perbuatan pidana seperti unsur tindak pidana pencurian dan unsur tindak pidana penipuan serta tindak pidana lainnya, baik dari sisi unsur objektif maupun unsur subjektif $^{19}$. Kedua, jika tidak dicantumkannya sertifikat keandalan (logo trustmark) menyebabkan kerugian yang berkaitan dengan produk (baik barang dan/atau jasa) sebagai objek transaksi, maka pelaku usaha dapat dimintakan pertanggunjawaban secara perdata (gantirugi) sebagaimana tercantum dalam Pasal 19 ayat (1) dan (2) Undang-Undang No.8 Tahun 1999 tentang Perlindungan Konsumen. Namun demikian tanggung jawab pelaku usaha untuk memberikan ganti rugi tersebut tidak berlaku apabila pelaku usaha dapat membuktikan bahwa kesalahan tersebut merupakan kesalahan konsumen. Hal ini berarti bahwa pembuktian terhadap ada tidaknya unsur kesalahan dalam gugatan ganti rugi merupakan beban dan tanggung jawab pelaku usaha ${ }^{20}$.

Dalam hal membahas terkait kerugian konsumen, secara tidak langsung akan berkaitan dengan penyelesaian sengketa. Penyelesaian sengketa timbul apabila ada salah satu para pihak mengalami kerugian. Dalam Pasal 72 ayat (1) Peraturan Pemerintah No. 80 Tahun 2019 tentang Perdagangan Melalui Sistem Elektronik mauapun UndangUndang No. 8 Tahun 1999 membagi penyelesaian sengketa dalam perdagangan melalui sistem elektronik (e-commerce) menjadi dua cara, pertama, melalui mekanisme internal dispute resolution dan kedua, melalui external dispute resolution. Cara penyeleseaian sengketa melalui external dispute resolution dapat ditempuh melalui jalur litigasi atau non-litigasi. Proses penyelesain sengketa melalui pengadilan ini akan menghasilkan suatu keputusan menang atau kalah bagi salah satu pihak. ${ }^{21}$. Untuk penyelesaian di luar pengadilan, penyelesaian sengketa konsumen ini diatur dalam Pasal 47 Undang-Undang No. 8 Tahun 1999 tentang Perlindungan Konsumen yang menyatakan:

"Penyelesaian sengketa konsumen di luar pengadilan diselenggarakan untuk mencapai kesepakatan mengenai bentuk dan besarnya ganti rugi dan/atau mengenai tindakan tertentu untuk menjamin tidak akan terjadi kembali atau tidak akan terulang kembali kerugian yang diderita oleh konsumen.

Penyelesaian melalui BPSK dapat dilakukan dengan cara mediasi, konsiliasi, atau arbitrase. Ketiga cara penyelesaian sengketa konsumen di luar pengadilan tersebut didasarkan atas pilihan dan persetujuan para pihak yang bersengketa dan bukan proses penyelesaian sengketa secara berjenjang.

\footnotetext{
19 Sahat Maruli Tua Situmeang, "Penyalahgunaan Dara Pribadi Sebagai Bentuk Kejahatan Sempurna Dalam Perspektif Hukum Siber”, SASI Jurnal Universitas Pattimura Ambon, Vo.27 No.1, 2021, hlm.3.

${ }^{20}$ Rachmadi Usman, Hukum Ekonomi Dalam Dinamika, Jakarta: Djambatan, 2000, hlm. 218.

${ }^{21}$ Amriani Nurnaningsih, Mediasi Alternatif Penyelesaian Sengketa di Pengadilan, Jakarta: PT Grafindo Persada, 2012, hlm.35.
} 
Dialogia Iuridica: Jurnal Hukum Bisnis dan Investasi

Volume 13 Nomor 1, November 2021

\section{PENUTUP}

Berdasarkan pembahasan sebagaimana dalam uraian di atas, dapat ditarik suatu kesimpulan bahwa pencantuman sertifikat keandalan (logo trustmark) yang dikeluarkan oleh Lembaga Sertifikasi Keandalan Asing yang digunakan oleh beberapa pelaku usaha di Indonesia belum dapat ditentukan secara tegas keabsahannya. Hal ini dikarenakan dalam Peraturan Pemerintah No. 71 Tahun 2019 tentang Penyelenggara Sistem dan Transaksi Elektronik tidak terdapat ketentuan yang mengatur terkait hal ini, sehingga pencantuman sertifikat keandalan (logo trustmark) tersebut masih dapat diterapkan selama belum ada pengaturan lebih lanjut. Namun demikian kebijakan yang akan diberlakukan bagi Penyelenggara Sistem Elektronik yang berdomisili dan melakukan kegiatannya di Indonesia, pencantuman sertifikat keandalannya (trustmark) harus dikeluarkan oleh/dikeluarkan dari Lembaga Sertifikasi Keandalan Indonesia, sedangkan untuk Penyelenggara Sistem Elektronik Asing diperbolehkan menggunakan Lembaga Sertifikasi Keandalan Asing sepanjang memenuhi kriteria yang dipersyaratkan. Berkaitan dengan sikap pemerintah terhadap perusahaan yang telah mencantumkan sertifikat keandalan (trustmark) dari Lembaga Sertifikasi Asing tersebut, hal ini akan disesuaikan kembali dengan ketentuan dalam Peraturan Menteri yang mengatur Lembaga Sertifikasi Keandalan yang akan diterbitkan. Apabila hal tersebut diatur, maka setiap Penyelenggara Sistem Elektronik Indonesia harus menyesuaikan dengan aturan tersebut (apabila memang harus disertifikasi ulang) dalam jangka waktu tertentu. Dengan tidak tercantumnya sertifikat keandalan (trustmark), hal tersebut dapat memberikan kerugian bagi konsumen, oleh karena itu tindakan hukum yang dapat dilakukan adalah:

a. Bagi pelaku usaha yang melanggar ketentuan tersebut akan dikenakan sanksi administratif sebagaimana diatur dalam Pasal 80 Peraturan Pemerintah No. 80 Tahun 2019 tentang Perdagangan Melalui Sistem Elektronik.

b. Bagi konsumen, jika terkait dengan penyalahgunaan data pribadi dan/atau penipuan oleh pelaku usaha atau pihak-pihak lain yang tidak berhak, maka dimungkinkan untuk mengajukan tuntutan secara pidana, sedangkan jika berkaitan dengan produk ataupun proses transaksi, konsumen dapat meminta pertanggungjawaban terhadap pelaku usaha dengan mengajukan gugatan atas kerugian yang dialami. Dalam hal penyelesaian sengketa konsumen, konsumen dapat memilih untuk menyelesaikannya melalui pengadilan atau di luar pengadilan, melalui lembaga yang bertugas menyelesaikan sengketa antara konsumen dan pelaku usaha yaitu BPSK.

Berdasarkan uraian yang telah dijelaskan sebelumnya, maka saran terkait pembahasan yang telah diuraikan sebagai berikut:

1. Perlu segera dibentuk Lembaga Sertifikasi Keandalan sebagaimana diamanatkan untuk memenuhi rasa keamanan dan kenyamanan dalam bertransaksi secara elektronik sekaligus juga memenuhi aspek perlindungan bagi konsumen $e$ commerce. 
Dialogia luridica: Jurnal Hukum Bisnis dan Investasi

Volume 13 Nomor 1, November 2021

2. Segera menyusun peraturan yang mengatur secara khusus tentang pelaksanaan Lembaga Sertifikasi Keandalan di Indonesia dan menetapkan Lembaga Sertifikasi Keandalan yang sah mengeluarkan sertifikat keandalan (logo trustmark) termasuk di dalamnya ketentuan mengenai sertifikasi keandalan yang dikeluarkan oleh Lembaga Sertifikasi Keandalan asing.

3. Perlunya pengaturan kembali terkait ketentuan pengenaan sanksi atas kewajiban pencantuman sertifikat keandalan (trustmark) sebagaimana diatur dalam Peraturan Pemerintah No. 80 Tahun 2019 tentang Perdagangan Melalui Sistem Elektronik. Dalam hal ini, Kementerian Komunikasi dan Informatika dan Kementerian Perdagangan perlu saling berkoordinasi dan memberikan ketegasan siapa pihak yang akan menjatuhkan sanksinya dan bagaimana bentuk sanksi yang akan dikenakan.

\section{DAFTAR PUSTAKA}

\section{Buku}

Amriani Nurnaningsih, Mediasi Alternatif Penyelesaian Sengketa di Pengadilan, Jakarta: PT Grafindo Persada, 2012.

Arsyad Sanusi, Hukum E-Commerce, Jakarta: Sasrawarna Printing, 2011.

Arum Laksana Nugraheni, Bunga Rampai: Berbagai Aspek Hukum dalam Transaksi secara Digital di Masa Pandemi COVID-19, Jakarta: Universitas Katolik Atma Jaya, 2021.

Bernadetta Tjandra Wulandari, Bunga Rampai: Berbagai Aspek Hukum dalam Transaksi secara Digital di Masa Pandemi COVID-19, Jakarta: Universitas Katolik Atma Jaya, 2021.

Husni Syawali dan Neni Sri Imaniyati, Hukum Perlindungan Konsumen, Bandung: Mandar Maju, 2000.

Johanes Gunawan, Hukum Perlindungan Konsumen, Bandung: Universitas Katolik

Parahyangan, 1999.

Rachmadi Usman, Hukum Ekonomi Dalam Dinamika, Jakarta: Djambatan, 2000.

Riyeke Ustadiyanto, Framework E-Commerce, Yogyakarta: Andi, 2001.

Soerjono Soekanto dan Sri Mamudji, Penelitian Hukum Normatif (Suatu Tinjauan Singkat), Jakarta: Rajawali Pers, 2001.

Yusuf Shofie, Sinopsis dan Komentar Undang-Undang Perlindungan Konsumen (Panduan Bagi Konsumen dan Pelaku Usaha), Jakarta: Perum Percetakan Negara, 2008.

\section{Jurnal}

Eka Nugraha Putra, et.al, "Efektivitas Pelaksanaan Sertifikasi Keandalan Website Jual Beli Online dalam Menanggulangi Penipuan Konsumen", Jurnal Cakrawala Hukum, Vol.8 No.2, 2017. 
Dialogia luridica: Jurnal Hukum Bisnis dan Investasi

Volume 13 Nomor 1, November 2021

Nufransa Wira Sakti, "Perpajakan dalam E-Commerce, Belajar dari Jepang", Berita Pajak No. 1443/Tahun XXXIII, 2001.

Sahat Maruli Tua Situmeang, "Penyalahgunaan Dara Pribadi Sebagai Bentuk Kejahatan Sempurna Dalam Perspektif Hukum Siber”, SASI Jurnal Universitas Pattimura Ambon, Vo.27 No.1, 2021.

Valerie Paskalia Selvie, "Perlindungan Konsumen dalam Transaksi Electronic Commerce: Perspektif Australia”, Legality, Vol.11 No.1, 2003.

Zainatun Rossalina, et.al, "Keabsahan Akta Notaris yang Menggunakan Cyber Notary sebagai Akta Otentik”, Jurnal Hukum Universitas Brawijaya, 2016.

\section{Thesis}

Paolo Balboni, Trustmarks: Third Party Liability of Trustmark Organisations in Europe, Thesis, 2008.

\section{Peraturan}

Undang-Undang No. 8 Tahun 1999 tentang Perlindungan Konsumen

Undang-Undang No.11 tahun 2008 tentang Informasi dan Transaksi Elektronik

Undang-Undang No.19 Tahun 2016 tentang Perubahan Atas Undang-Undang No. 11

Tahun 2008 tentang Informasi dan Transaksi Elektronik

Peraturan Pemerintah No. 71 Tahun 2019 tentang Penyelenggara Sistem dan Transaksi Elektronik

Peraturan Pemerintah No. 80 Tahun 2019 tentang Perdagangan Melalui Sistem Elektronik

\section{Pranala Luar}

Cambridge

Dictionary,

Certification, https://dictionary.cambridge.org/dictionary/english/certification, ditelusuri pada 1 Maret 2021.

Chyntia Hutagalung, Perlindungan Hukum Terhadap Konsumen Dalam Kegiatan ECommerce, https://www.pphbi.com/perlindungan-hukum-terhadap-konsumendalam-kegiatan-e-commerce-di-indonesia/, diakses pada tanggal 18 Oktober 2021 pukul 14.25 WIB.

Febrani D. A Putri, Lembaga Sertifikasi Keandalan: Rancangan Permen Akan Pacu LSK Lokal, https://teknologi.bisnis.com/read/20130401/105/5967/lembaga-sertifikasikeandalan-rancangan-permen-akan-pacu-lsk-lokal, diakses pada tanggal 14 Maret 2021 pk.10.09 WIB.

Indah Rahmayani, Sambut Positif Pembatalan Sertifikasi, https://kominfo.go.id/index.php/content/detail/6143/Sambut+Positif+Pembatalan+ Sertifikasi/0/sorotan_media, diakses pada tanggal 9 Maret 2021 pk.13.45 WIB. 
Dialogia luridica: Jurnal Hukum Bisnis dan Investasi

Volume 13 Nomor 1, November 2021

Moderator, Perdagangan Melalui Sistem Elektronik (PMSE), https://www.pajakku.com/forum-topic/5ea13ab1d066f279c7d5c4ae/PerdaganganMelalui-Sistem-Elektronik-(PPMSE), diakses pada tanggal 22 Februari 2021 pk.14.10 WIB 